ten per cent by two strains of the virus. The other clone was not reduced in yield by either strain. These results agree with earlier studies by the same workers. It is also concluded that the reaction of the virus upon a particular clone may be considerably affected by environmental conditions.

\section{Industrial Research and Management}

A REPORT of the conference of industrial research directors and managers held at Ashorne Hill, Leamington Spa, during March 11-14 (see Nature, 163,828 ; 1949), has now been published (pp. 123; London: Federation of British Industries, 1949; 2s. 6d.). It includes the papers presented in full, with summaries of the contributions to the discussion. A list of delegates and a list of publications of the Industrial Research Committee of the Federation of British Industries are appended.

\section{Discussion on Heterogeneous Catalysis}

THE Faraday Society is organising a general discussion on heterogeneous catalysis, to be held at the New Arts Theatre, University of Liverpool, during April 12-14, with Sir John Lennard-Jones in the chair. As a general introduction, Prof. H. S. Taylor, professor of physical chemistry in Princeton University, will deliver the Spiers Memorial Lecture (the first since the Second World War), his subject being "Surface Catalysis : Retrospect and Prospect"; this Lecture was founded in memory of Mr. F. S. Spiers, one of the founders, and secretary during 1903-26 of the Society. Forty-two papers have been prepared for the discussion, in the following four sections : (1) theories of adsorption and properties of surface layers; (2) adsorption and catalysis on metals; (3) adsorption and catalysis on oxides; (4) techniques. It is hoped to circulate advance proofs of the papers by March 29, and at the discussion authors will only be allowed to speak for five minutes on salient points. Further particulars can be obtained from the Secretary, Faraday Society, 6 Gray's Inn Square, Gray's Inn, London, W.C.1.

\section{Conference of the Stress Analysis Group of the Institute of Physics}

TuE Stress Analysis Group of the Institute of Physics will be holding its fourth annual conference during April 3-5 at University College, London. The conference will begin at 3.30 p.m. on April 3 with a session on brittle lacquers. The morning session of April 4 will be devoted to papers and discussions on the use of models in structural work, including structural engineering, shipbuilding and aircraft construction. In the afternoon the topic will be on recent developments in photo-elasticity. The morning and afternoon sessions of April 5 will be devoted to papers and discussions on the application of experimental stress-analysis methods to soil mechanics problems, and on experimental stress-analysis methods in the motor industry, respectively. The conference will be open to the public. Further particulars can be obtained from the honorary secretary of the Stress Analysis Group, Mr. E. K. Frankl, Engineering Laboratory, Cambridge.

\section{Fellowships for Cancer Research}

The British Empire Cancer Campaign is inviting applications for fellowships in cancer research. Senior fellowships will normally be tenable for seven years at a salary of $£ 2,000$ rising by $£ 100$ increments to $£ 2,600$ per annum; junior fellowships will be tenable for three years at a salary of $£ 1,000$ rising by $£ 100$ increments to $£ 1,200$ per annum. Fellowships are open to graduates of British nationality with no restrictions as to age, although the election of a junior fellow above the age of thirty-five is unlikely. The first elections will take place in June this year, and work, if possible, will begin on October 1. Fellows must carry on their research initially in Great Britain or in Northern Ireland, and only at the place at which they are authorized by the Campaign to work. The fares of successful candidates from overseas will be paid by the Campaign. Further particulars and application forms, to be returned by May 1 , can be obtained from the General Secretary, 11 Grosvenor Crescent, Hyde Park Corner, London, S.W.1.

\section{Cecil Peace Prize}

The 1949 award of the Cecil Peace Prize has been divided between Mr. M. Foss, of Jesus College, Cambridge, and Mr. P. J. Gilder, of King's College, Cambridge. The subject of the essay was "What international action should be taken with regard to the many millions of displaced or expelled persons and refugees in Western Europe, with a view to both the restoration of European economy and to the utilisation of labour power now running to waste". The Prize is an annual award, worth $£ 100$, and is open to all members (less than twenty-five years old) of the universities of the United Kingdom. The subject for 1950 is : "What is meant by the Balance of Power? And has its attempted maintenance since 1660 been useful for Peace or not ?" Essays must be sent in before November 1 to the Secretary, Association of Universities of the British Commonwealth, 5 Gordon Square, London, W.C.1.

\section{Announcements}

Gustavo ColonNeTtr has been elected correspondant for the Mechanics Section of the Paris Academy of Sciences in place of M. Maurice Roy, who has been elected a member of the Section. Hans A. Pallmann has been elected correspondant for the Section of Rural Economy in place of the late M. André Boivin.

Mr. F. P. Slater, of Fine Spinners and Doublers, Ltd., Rock Bank, Bollington, near Macclesfield, has been elected an honorary life member of the Textile Institute, in recognition of his services to the Institute.

THE Chemical Society invites applications for grants for research in all branches of chemistry. Such applications must be submitted on the appropriate form, not later than May 1, to the General Secretary, Chemical Society, Burlington House, Piccadilly, London, W.1, from whom further particulars can be obtained.

As international symposium on ultrasonics, organised by the Italian National Research Council and the Italian Physical Society with the collaboration of the International Union of Physics, will be held in Rome during June 14-17. Arrangements for the symposium are being made by Prof. Amadeo Giacomini, professor of physics, University of Trieste.

A IIsT of papers, corrected to January 21, has recently been published in connexion with the Fourth World Power Conference, to be held in London during July 10-15 (see Nature, December 17, 1949, p. 1035). Applications for membership can still be accepted, the forms being obtainable from the Offices of the Fourth World Power Conference, 414 Cecil Chambers, 76 Strand, London, W.C.2. 